\title{
Pandemi Sonrasında Kent Mekânının İki Yüzü: Düşler ve Gerçekler
}

\author{
* \\ Emel Akın ${ }^{1}$ \\ ORCID: 0000-0001-5367-4373
}

\section{Öz}

Epidemiler ve pandemiler, toplumsal yapıları ve mekânları yeniden biçimlendiren koşullara ortam hazırlamıştır. Mart 2020'de pandemi olarak ilan edilen COVID-19 hastalı̆̆ s sürecinde, gündelik yaşam ve kentsel mekânların kullanım yeni bir sürece evrilmiştir. Vaka sayılarının, aşıların, pandeminin bireyler ve yaşam tarzları üzerindeki etkilerinin yanı sıra pandemi sonrasının ekonomik, toplumsal yapılanması ve kent mekânları, dünya gündeminin baş aktörleri olmuştur. Makalenin amacı, pandemi sonrasının kentsel ve kamusal mekânlarını "düşler" aracılığıyla kurgulamak, kurulan düşlerin gerçekleşip gerçekleşemeyeceği sorusuna yanıt aramaktır. Makalede, tarihsel süreçte yaşanan pandemilerden ve epidemilerden söz edilmekte, pandemi öncesinin kent mekânlarına değinilmekte, pandemi sonrasının kentsel biçimlenmesine ilişkin iki farklı "düş" kurulmaktadır. Mekân üretimi sürecinin "gerçek"leri; ekonomik yapı, planlama ve mekân biçimlenme ilişkilerinin kuramsal çerçevesi aktarılmakta; makalede kurulan düşlerin gerçekleşip gerçekleşemeyeceği bu kuramsal çerçevede irdelenmektedir. Pandemi sonrasının ekonomik yapılanması, üretim biçimi ve ideolojisi kent mekânlarımın biçimlenmesini belirleyecektir. Dolayısıyla, geleceğin kent mekânları için kurulan düşlerin, gerçekleşip gerçekleşmeyeceğini kestirmek zordur. Makalede, geleceğin mekânları için üç farklı seçenek üretilmiştir. Yeni dönemin olası sonuçların tahmin etmek çok kolay olmasa da, kentler, değişen ekonomik ve toplumsal yaprya koşut olarak biçimlenecektir.

Anahtar Kelimeler: Covid-19, pandemi, kentsel kamusal mekân, sermaye

\footnotetext{
${ }^{1}$ Dr. Öğr. Üyesi, Atılım Üniversitesi, E-mail: emel.akin@atilim.edu.tr idealkent @ Kent Araştırmaları Dergisi (Journal of Urban Studies) http://idealkentdergisi.com
} 


\title{
Two Faces of Urban Spaces after Pandemic: Dreams and Realities
}

\author{
Emel Akin² \\ ORCID: 0000-0001-5367-4373
}

\begin{abstract}
In the process of COVID-19 disease, declared as a pandemic in March 2020, everyday life and the use of the urban space has evolved into a completely new process. The aim of this article is to construct the post-pandemic urban and public spaces through "dreams" and to seek an answer to the question of whether the dreams can come true or not. In the article, pandemics and epidemics in the historical process are mentioned, the urban spaces of the pre-Covid-19 pandemic are briefly reviewed, and for the post-pandemic era, two different "dreams" are established regarding the future urban and public spaces. The "realities" of the space production process, the theoretical framework of the relations of economic structure, planning and space formation are conveyed, and whether the dreams set up in the article can come true or not is examined in this theoretical framework. It is difficult to predict whether the dreams for the urban spaces of the future will come true. In the article, three different options are produced for the spaces of the future. Although it is not easy to predict the possible outcomes of the new era, cities will be shaped in line with the changing economic and social structure.
\end{abstract}

Keywords: Covid-19, pandemic, urban public space, capital.

\footnotetext{
2 Assist. Prof., Atllım University, E-mail: emel.akin@atilim.edu.tr idealkent (c) Kent Araştırmaları Dergisi (Journal of Urban Studies) 


\section{Giriş}

Aralık 2019'da başlayan ve Mart 2020'de, Dünya Sağlık Örgütü tarafından pandemi olarak ilan edilen COVID-19 salgını, fiziksel ve psikolojik olarak insan sağllğında olumsuz sonuçlara neden olmuştur, olmaya da devam etmektedir. Pandemi, epidemi, salgın, bulaş, filyasyon, entübe gibi terimler gündelik dile yerleşmiştir. Epidemi ve pandemi, bir hastalığın, salgının yayılmasını tanımlamak için kullanılan terimlerdir. Dünya Sağlık Örgütü'ne göre, epidemi, belli bir zaman diliminde, bir toplulukta ya da bölgede yayılan hastalığa verilen isimdir. Epidemiler, hastalığın çıtı̆̆ bölgeye, nüfusun ne kadar etkilendiğine bağlı olarak farklılık gösterebilir. Pandemi, Dünya Sağlık Örgütü kapsamında olan en az 3 ülkeye yayılan bir epidemi türüdür ve bir hastalığın dünya genelinde yayılması olarak tanımlanmaktadır (Lockett, 2020). Endemi, Sağlık Bakanlığ'na (2019) göre, belirli bir toplumda belirli bir zaman diliminde, bir enfeksiyon hastalığına yakalanan bireylerin sayısındaki beklenenden fazla artış durumudur. Türkiye Bilimler Akademisi'nin (TÜBA) hazırladığı COVID-19 Pandemi Değerlendirme Raporu'nda (2020a), pandemi "(eski Yunanca'dan pan: tüm + demos: insanlar), dünyada birden fazla ülkede veya kıtada, çok geniş bir alanda yayılan ve etkisini gösteren salgın hastalıklara verilen genel isim" olarak tanımlanmıştır. TÜBA'nın Raporu'na göre, "pandeminin insanlar üzerindeki yüksek etki derecesi, virüsün enfektivitesine ve virülansina, toplum bağışıklı̆̆ına, bireylerin yaşam alışkanlıklar ve sosyo ekonomik durumlarnna, bireylerin ülkeler ve şehirlerarası mesafe aşım kolaylklarına, bireylerin yaşamında ve çalışma hayatındaki taşıldı̆̆ risk faktörlerine, bulundukları ülkedeki sağllk hizmetlerinin kalitesine ve salgin etkenin iklime bağh olarak olumlu ya da olumsuz tavır değiştirme kabiliyetine sahip olmasına göre değişiklik göstermektedir". Covid-19 pandemisi ile birlikte yeni bir yaşam biçimi başlamış, mekânların kullanımı değişmiştir. Evlere kapanılan, mesafeli (mutlaka bir sıfat konulacaksa fiziksel, bedensel ya da bireysel mesafe), temassız ve hijyenik yeni yaşam tarzl, ev, kamusal alan, kentsel mekân tartışmalarını artırmış, doğayı, tarımı, yeşili gündeme taşımıştır.

Tarihsel süreçte uzun sürelerle ve sıklıkla yaşanan epidemiler ve pandemiler, toplumsal yapıları ve mekânları yeniden biçimlendiren koşullara ortam hazırlamıştır. Salgın hastalıklar insan sağlığının biyolojik tehditleridir hiç kuşkusuz. Bununla birlikte, salgın hastalıkların nedenleri, sonuçları ve sonrasındaki olası koşullar, toplumsal üretim biçiminden bağımsız bir şekilde ele alınmamalıdır. Kentsel ve kamusal mekânların nasıl biçimleneceği ve birey- 
kamusal alan ilişkisinin nasıl sağlanacağı sorularının yanıtı, mekân üretiminde aranmalıdır. Mekânları içinde bulundukları toplumsal koşullar biçimlendirir; karşılıklı olarak, mekânlar da toplumsal yapıyı etkiler. Bir başka deyişle, toplumun sosyo-ekonomik ve ideolojik yapılanması mekânları değiştirirken mekânlar da gündelik hayatın, kültürel yapının değişiminde etkili olur.

Pandemi ile birlikte, değişen yaşam tarzı, "ev"lerin ve kamusal alanların mekânsal özeliklerini bir kez daha tartışmaya açmıştır. İçinde bulunulan zorlu pandemi sürecinin sonrasında, geleceğin kent mekânlarının nasıl biçimleneceğine ilişkin tahminler yapılmakta, önerilerde bulunulmaktadır. Gelecekte, kamusal alan ve toplum-birey ilişkisinin nasıl dönüşe(bile)ceği ve nasıl dönüşmesi gerektiği tartş̧ılmaktadır. Pandemi öncesinde kentsel mekân biçimlenmelerinin ve kamusal alan kullanımlarının bir kez daha hatırlanmaya ihtiyacı vardır: Bugüne dek, toplumsal/kamusal yarar sağlayan ve planlama ilkeleri temelinde yapılmış olan tasarımlar, uygulanmış mıdır, uygulanabilmiş midir? Uygulan(a)madiysa nedenleri nedir? Kamusal alanların ve kentsel mekânların kullanımındaki, biçimlenmesindeki sorunlar pandemi nedeniyle mi ortaya çıkmıştır? Pandemi öncesinde kamusal alanlar etkin ve verimli kullanılabiliyor muydu? Pandemi sonrasının olası yeni uygulamaları, düşük gelir gruplarının mevcut mekânsal sorunlarını çözebilir mi? Bunlara benzer pek çok sorunun yanıtı mekân üretim sürecinin karmaşık ilişkileri temelinde aranmalıdır.

Makalenin amacı, pandemi sonrasında, geleceğin kentsel mekânlarını "düşler" aracılığıyla kurgulamak, kurulan düşlerin gerçekleşme olasılığını, mekân üretiminin karmaşık ilişkileri temelinde sorgulamaktır. Makale kapsamında, öncelikle tarihsel süreçte yaşanan salgın hastalıklara ve pandemilere değinilmekte, ardından pandemi öncesinin kent mekânlarının biçimlenmesine ilişkin bilgi verilmekte ve pandemi sonrasının kent mekânlarına ilişkin iki farklı "düş" kurulmaktadır. Kent düşlerinin gerçekleşip gerçekleşemeyeceği, mekân üretim sürecinin kuramsal temelinde sorgulanmaktadır.

\section{Tarihsel Süreçte Pandemiler ve Epidemiler (Salgın Hastalıklar)}

Epidemiler ve pandemiler (salgın hastalıklar), virüslerin organizmaların üzerindeki etkisi, mutasyon gibi süreçlere sahiptir. Salgin hastalıklar toplumsal, politik ve ekonomik koşulların belirleyiciliğinde gerçekleşirken, karşılıklı olarak, salgın hastalıklar da toplumsal yapıyı değiştirmektedir. Tarihsel süreç içinde salgın hastalıklar, ekonomik, politik, kültürel yapılanmanın; kısaca toplumsal yapının ve kent mekânlarının değişimine zemin hazırlamıştır. 
Avc1-toplayıcı gruplardan oluşan ilk insan topluluklarında etkileşimin az olması nedeniyle, hastalıkların yayılma oranı düşüktür. Yerleşik hayata geçilmesi ve insanlar arasındaki etkileşimin hızlanmasıyla hastalıkların yayılma seyri değişmiş; salgın hastalıkların bilinirliği artmıştır (Tunç ve Atıcı, 2020). Neolitik Devrim'le ortaya çıan tarım toplumunda, evcilleştirilen hayvanlarda bulunan virüsler ve patojenler, insanlara geçmiş, zaman içinde 'medeni hastalık havuzları' olarak geniş bölgelere/alanlara yayılmıştır. Ticaret yollarının artması ve savaşlar yeni hastalıkları ortaya çkarmıştır (Choonara, 2020). Antik dönemde, Yunan, Mısır, Çin, Mezopotamya ve Mısır'da salgın hastalıklar görülmektedir. Antik Roma'da, nüfus yoğunluğunun fazla olması, kentsel hizmetlerin yetersizliği, suya erişim ${ }^{3}$ ve alt yap1 ${ }^{4}$ sorunları nedeniyle, kolera, tifüs, dizanteri, sarılık, sıtma, kızamık, çiçek ve çocuk felci salgınları sıklıkla yaşanmıştır (Tuğaç, 2020).

Tarihsel süreçte, toplumsal yapıları etkileyen 3 büyük veba, 7 kolera ve 10'dan fazla grip pandemisinin yanı sıra epidemik boyutta çiçek, sarıhumma ve sıtma hastalıkları görülmüştür (Türkiye Bilimler Akademisi-TÜBA, 2020b). Bilinen en eski pandemi, M.Ö. 429-426 yılları arasında Yunanistan'da 75.000 ile 100.000 kişinin ölümüyle sonuçlanan Atina Vebasıdır: Veba, Atina Şehir Devleti ile Spartalılar arasındaki Peleponnessos Savaşı'nın seyrini değiştirmiş; Atinalıların yasalara ve dine bağlılıklarını azaltmıştır (Tunç ve Atıc1, 2020). 165-180 yılları arasında Roma İmparatorluğu'nda görülen Antoninus Vebasında 5 milyona yakın insan hayatını kaybetmiştir. Kentlerde sanitasyona ${ }^{5}$ önem verilmesine, büyük kanallar ve hamamlar inşa edilmesine (Özcü ve Sayan Atanur, 2020) rağmen veba, İmparatorluğun gücünün zayıflamasına ve Hristiyanlığın popülerleşmesine zemin hazırlamıştır. 541-542 yılları arasında 1. Veba Salgını olarak bilinen ve Bizans Başkenti Konstantinopolis'te başlayan Justinianus Vebası, Avrupa'da 25-50 milyon arasında insanın ölümü ile sonuçlanmış; Bizans İmparatorluğu'nun çöküşüne neden olacak koşulları yaratmıştır (Tunç ve Atıc1, 2020). Orta Çağ kentlerinin ekonomik yapılanması, altyapı sorunları ve kentsel hizmet yetersizlikleri, 14. yüzyılda başlayan ve 10 yıldan uzun döngülerle tekrarlanan Kara Veba/Kara

\footnotetext{
${ }^{3}$ Suya, sosyal statüsü yüksek kişiler erişebilmektedir: Çok katlı apartmanlarda su, sadece ev sahibinin yaşadığı zemin katta vardır.

${ }^{4}$ Atıklar doğrudan sokağa atılmakta ya da merdiven altındaki sarnıçlarda biriktirilerek toplanmaktadır.

${ }^{5}$ Hijyen için gerekli koşulların sağlanması ve korunması.
} 
Ölüm salgınına ${ }^{6}$ neden olmuştur. Hastalık, deniz yoluyla diğer bölgelere yayılmış, sadece Avrupa'da 20 milyon kişi ölmüştür (Türkiye Bilimler Akademisi-TÜBA, 2020b). Kara Veba pandemisi, ekonomik, toplumsal ve mekânsal değişimlere temel oluşturmuştur: 1378-82 yılları arasında tüm Avrupa kıtasında devrimci ayaklanmalar ve isyanlar başlamış, sosyal ve psikolojik problemler ortaya çıkmıştır. Kentlerin temizliği sağlanmış, değişen ekonomik yapılanmaya koşut olarak kent sınırları genişlemiştir. Justinianus ve Kara Veba salgınlarının orta ve uzun vadede önemli ekonomik sonuçları olmuştur: Büyük nüfus kayıpları, ekonomik faaliyetlerde ve gelir bölüşümünde büyük değişikliklere yol açmıştır. Ekilen toprakların büyük bölümü boş kalmış, azalan talep nedeniyle tahılların ve genel olarak tarımsal malların fiyatları düşmüş, emek darlığı nedeniyle ücretler iki katına çıkmıştır. Böylece tarım üreticilerinin ve özellikle toprak sahiplerinin gelirleri düsserken, emek gelirleri artmıştır. Vebadan kurtulanlar, ücretlerin yükselmesi ve ölenlerin mallarını devralmaları sayesinde, gelirlerini ve yaşam standartlarını yükseltmiştir (Pamuk, 2020). Salgin nedeniyle ticaret neredeyse durma noktasına gelmiş, Avrupalı tüccarlar, dünyanun başka yerlerinde yeni pazarlar ve kaynaklar aramaya yönelmiştir (Beyaz, 2021). Ekonomik yapılanmadaki etkisi nedeniyle veba, feodalizmin çözülmesine ve kapitalizmin alt yapısının oluşmasına zemin hazırlamıştır.

Avrupalıların Amerika'yı sömürgeleştirme sürecinde, salgın hastalıkların yayılma alanı artmış; Orta Meksika nüfusunun \% 90'1 yok olmuştur. 17. yüzyılda, Amerika kıtasından Avrupa'ya yayılan ölümcül bir çiçek hastalığı nedeniyle, 18. yüzyıl başında 400 bin kişi ölmüştür. İngiltere'nin sömürgeleştirme sürecinde Hindistan'daki kolera salgını, hızla tüm dünyaya yayılmış (Beyaz, 2021), 1826-1918 yılları arasında yedi büyük kolera pandemisi yaşanmıştır. Bir başka salgın hastalık, epidemi ya da pandemi olarak yayılan griptir. İlki, İtalya ve Fransa'da görülen 1173 tarihli grip epidemisidir. 1580 tarihinde Asya'da başlayan ve tüm kıtalara yayılan ilk grip pandemisinden sonra, sırasıyla 1729-1733 yılları arasında Rusya'da, 1781 yılında Çin'de, 1890 yılında yine Rusya'da başlayan üç grip pandemisi yaşanmıştır (Tunç ve Atıcı, 2020).

18.-19. yüzyılda, Sanayi Devrimi sürecinde, fabrikaların yakınındaki işçi konutlarının sağlıksız nitelikleri, alt yapının olmaması, tifo, kolera, dizanteri ve tüberküloz hastalıklarına neden olmuştur. Engels (1975 ve 2019), işçi sınıfı arasında hastalıkların yayılmasını kolaylaştıran sağlıksız ve kötü yaşam ortamlarından, yoksul mahallelerde ve büyük kentlerin dar sokaklarında, güneş almayan, sıkışık, kalabalık ve kirli işçi konutlarından bahsetmekte ve tüm

${ }^{6}$ Kara Veba, Mısır'dan, gemilerdeki fareler aracılı̆̆ıyla taşınmış ve yayılmıştır. 
olumsuzlukların nedenlerinin üretim biçiminde ve örgütlenmesinde, toplumsal çevrede aranması gerektiğini vurgulamaktadır. Yoksul işçi bölgelerinde artan hastalıklar nedeniyle fabrikalarda çalışacak sağlıklı işçi bulunamadığı için ve orta ve üst gelir gruplarını hastalıklardan korumak amacıyla kentlerin olumsuz yaşam koşullarını iyileştirme çalışmaları başlatılmıştır (Benevolo, 1981): Yasal düzenlemeler yapılmış, kentlerde belediyecilik hizmetlerine başlanmış, modern kent planlamasının temelleri atılmış, alt yapı geliştirilmiş ve kent mekânları genişletilmiştir. 20. yüzyılda, 1918 yılında Domuz Gribi, 1957 yılında Asya Gribi ve 1968-1970 yıllarında Hong Kong Gribi pandemilerinde milyonlarca insan hayatını kaybetmiş̧tir. 21. yüzyılda, 2003 tarihinde SARS, 2009-2010 y1llarında Domuz Gribi, 2015 tarihinde MERS salgınları, neredeyse pandemi haline gelmiştir (Tunç ve Atıcı, 2020). Son olarak, günümüzde yaşanan COVID-19 pandemisi de tarihteki yerini almak üzeredir.

Tüm dünyada olduğu gibi Türkiye'nin tarihsel sürecinde de salgin hastalıklar sıklıkla yaşanmıştır. Anadolu Selçukluları döneminde, büyük veba salgınları, kitlesel ölümlere yol açarak büyük nüfus kayıplarına neden olmuştur. Osmanlı kentlerinde yüzyıllardır görülen sıtmanın kaynağı olan bataklıklar kurutulmaya çalışılmıştır. Avrupa'da 17. yüzyılda yayılan sıtmanın tedavisinde kullanılan kinin, Osmanlı'ya ancak 19. yüzyılda gelebilmiştir (Yiğit ve Gümüşçü, 2016). Kurtuluş Savaşı yıllarında da, sıtma ile mücadele edilmiştir. Osmanlı İstanbul'unda, 1831'de kolera salgını başladığında, sağlık ve belediye kurumsallaşması yoktur. Kolera mücadelesi, karantina uygulanarak, insan ve mal hareketliliği kısıtlanarak yapılmaktadır. 1865 'de, işçi sınıfının ve yoksul kesimin barındığı Kasımpaşa' da kolera vakası başlamış, kısa sürede bütün İstanbul'a yayılmıştır. Ölülerin kent merkezinde gömülmesi yasaklanmış; böylelikle mezarlık alanlarının dönüştürülmesinin yolu açılmıştır (Kıygı, 2020). Anadolu'da 17. yüzyıldan itibaren, sitma, veba, tifo, tüberküloz, tifüs ve cüzzam benzeri hastalıklar yaygınlaşmıştır. Veba, 17. yüzyıldan 19. yüzyıl başına kadar Osmanlı İmparatorluğu'nda sıklıkla görülmektedir. Veba salgınlarında en çok etkilenen yerlerin başında İstanbul ${ }^{7}$ gelmektedir. 1828 y1lında İstanbul vebadan kurtulmuş, hastalık yıllar içinde Manisa, Edremit, Balıkesir'e ve İzmir'e yayılmıştır. 1837 yılındaki veba salgını şiddetlidir; köylerin tamamen terk edilmesine, yer değiştirmesine ve bazı köylerin haritadan

\footnotetext{
7 İstanbul'da 1467, 1539, 1573, 1576, 1578, 1592, 1596, 1615, 1617, 1620, 1650, 1655 tarihlerinde ortaya çıkan veba salgını en etkilileri olarak sayılabilir (Yiğit, Gümüşçü, 2016).
} 
silinmesine neden olmuştur (Yiğit ve Gümüşçü, 2016). Anadolu'da veba, karantina ve diğer devletlerle işbirliği içerisinde yürütülen kordon ${ }^{8}$ uygulamaları ile önlenmeye çalışılmıştır (Tunç ve Atıc1, 2020).

Özetle, Atina Vebasından, Orta Çağ'ın Kara Vebasına/Kara Ölümüne, 1918 tarihli İspanyol gribine kadar yaşanan pandemiler ve endemiler, toplumların ekonomik yapılanmalarının değişiminde, dolayısıyla toplumsal yapının ve kent mekânlarının değişiminde etkili rol oynamıştır.

\section{Günümüzde: COVID-19 Pandemisinin Öncesinde Kent Mekânları}

Kapitalizmin doğası gereği belli periyotlarda sorun yaşayan sermaye, 1970'li yıllarda, tüm dünyada yeni bir krize girmiştir. Sermayenin sürekliliğinin sağlanması ve içinde bulunduğu krizin çözülmesi amacıyla 'küreselleşme' adı verilen yeni bir süreç başlatılmıştır. Küreselleşmenin temel hedefi olan, sermayenin ulusal ve uluslararası hareketliliği, neoliberal politikalarla sağlanacaktır. Türkiye de, 1980'li yıllardan itibaren yeniden yapılanma sürecine girmiş; neoliberal politikalar hemen her alanda uygulanmış, yeni yasal çerçeveler oluşturulmuştur (Akın, 2007). Ulusal ve uluslararası sermayenin hareketliliği, kârın/rantın en kolay ve hızlı elde edileceği kent topraklarında sağlanacaktır. Yapılaşmaya ilişkin yeni yasalar çıkartılmış, yeni kurumlar oluşturulmuş, planlama ve kamu/toplum yararı ilkelerinin göz ardı edildiği kararlar alınmıştır. 1980'lerin ilk yıllarından itibaren giderek artan biçimde, özellikle de 2000'li yılların başlarından bu yana kent mekânları görülmedik bir yapılaşma içindedir. Metropoller başta olmak üzere büyük kentlerde, kent çeperleri hızla yapılaşmaya açılmış, büyük ölçekli, yüksek katlı konut alanları kent mekânına hızla eklemlenmiştir. Mekânsal dönüşümün hızla yaşandığı kentlerde mekânsal ayrışma ve toplumsal kutuplaşma artmıştır: Sınıfsal farklar mekânlar üzerinden çok kolay okunmaktadır; varsıl, lüks kapalı siteler ve yüksek bloklar ile yoksul, çöküntü bölgeleri ve gecekondular bir aradadır. Yeşil alanların, tarım alanlarının çoğunluğu ve kentsel boşlukların bir kısmı yapılaşmaya açılmış, rantı yüksek olan bölgelerde kentsel dönüşüm uygulamaları çoğalmış, alışveriş-eğlence merkezleri çığ gibi büyümüştür. Kamusal alanlar ciddi biçimde zarar görmüş; rantı yüksek olanlar sermaye ve özelleştirme baskısıyla yapılaşmaya açılmış, pek çoğuna toplumun erişimi kısıtlanmıştır. Bugünün mega kent yapılaşması, kent mekânlarının rant alanlarına dönüşmesi, değişen ekonomi-politik kararlar ve tüketim endeksli yaşam

\footnotetext{
${ }^{8}$ Kordon, yani sahil şeridi uygulaması hastalığın belli bir yerleşkeden veya mahallinden dışarı çıkmasını engelleyen bir mücadele yöntemidir.
} 
tarzları nedeniyle doğal yaşam alanları zarar görmüş, çoğu geri dönülemez biçimde tahrip olmuştur (Akın, 2008, 2013). Doğanın değişen dengesi salgın hastalıklara davetiye çıkarmıştır.

Harvey (2020), COVID-19 pandemisini, neoliberalizm eliyle "kırk yılı aşkın bir süredir gerçekleştirilen doğa talanının intikamı" şeklinde değerlendirmektedir. Sermayenin kendini yeniden üretimi sürecinde çevresel koşulları değiştirdiğini ifade eden Harvey, "gerçekten doğal felaket diye bir şey olmadığını", bir mutasyonun yaşamı tehdit eden koşullarını insan faaliyetlerinin belirlediğini ve virüsün yayılmasının ekonomik ve demografik etkilerinin hegemonik ekonomik modelin mevcut çatlaklarına ve kırılganlıklara bağlı olduğunu vurgulamaktadır.

\section{Düşlerin Sınırı Yoktur: Covid-19 Pandemisinin Sonrasında Kent Mekânları}

Düşlerin sınırı yoktur; bu çalışmada da, pandemi sonrasının kent mekânlarına ilişkin iki farklı düş kurulmuştur:

Küçük bir “düş"ïn içinde bir kent: Günümüzde, pandemi sonrasının kent mekânlarına yönelik, akıllı kentler, yeşil alanların artırılması, kamusal alanlarda farklı tasarımlar, yeni mekânsal biçimlenmeler, vb. pek çok öneri geliştirilmektedir. Düşlerin sınırı yoktur: örneğin, tarım alanlarını ve yeşil alanları işgal eden binalar yıkılabilir, AVM'ler ortadan kaldırılabilir ya da işlevleri değiştirebilir, betonlaşmanın yerini açık kamusal alanlar, konser alanları, meydanlar alabilir, kentler, bisiklet yolları ile sarmallanabilir, sokaklar taşıtlara değil, çocuk oyun alanlarına bırakılabilir, vb.; kısaca tasarımcıların, birey ve toplumu odak alan planlamaları ile yaşanabilir bir kent yaklaşımı olabilir (olabilir mi?).

Büyük bir "düş"ün içinde bir kent: Barınma, üretim, iş, sağlık, eğitim, alışveriş, sosyal ve kültürel etkinlik vb. temel kentsel işlevlere, yaya veya motorsuz araçlarla ulaşılabilen kent üniteleri oluşturulabilir. Kent üniteleri, 15 dakikalık yürüme mesafesi hinterlandı olan alanlardan oluşabilir. Ki, bu modelin benzeri, Panthéon Sorbonne Üniversitesi Öğretim Üyesi Carlos Moreno tarafından geliştirilmiş; Paris'te denenmeye başlanmıştır (Peters, 2020). Düşlerin sınırı yoktur: Örneğin, üretim, barınma, çalışma, eğlenme, spor yapma, temel eğitim gibi farklı işlevlerin yürüme mesafesi içinde sağlandığı bir kent ünitesinde, farklı toplumsal sınıflar bir arada yaşayabilir. Bir başka ifadeyle, farklı ekonomik, kültürel ve sosyal sermayeye sahip gruplar, ayrışmaksızın, 
kutuplaşmaksızın ayn alanda yaşatılabilir. ${ }^{9}$ Bir fabrikanın sahibi ile hizmetlisi ve memuru; bir okulun müdürü, öğretmeni, öğrencisi ile hizmetlisi ya da bir sağlık merkezinin başhekimi, doktoru ile hasta bakıcısı aynı alanda barınabilir, aynı sosyal mekânları paylaşabilir. Her kent ünitesinin farklı temel üretim işlevleri olabilir: Teknoloji, tekstil, geri dönüşüm, atık malzemelerden sanat, gida, alkol, ilaç, temizlik malzemeleri, küçük ev mobilyası, vb. Bu kent ünitelerinin, günümüz gereksinimlerine koşut olarak, büyük hastanelerin, iş merkezlerinin, üniversitelerin olduğu bir de kent merkezi olmalıdır. Yeşil alanların, nüfus yoğunluğunun dikkate alındığı, çocuk oyun alanlarının küçük parklara ya da AVM'lere sıkıştırılmadığı, sokakların aktif kullanıldığı bir kent mekânı oluşturmak olanaklıdır (olanaklı mıdır?).

Her iki "düşs" için "olabilir mi?" sorusunun yanıtının "gerçek"lerde aranması gerekmektedir.

\section{Gerçekler: Mekân Üretimi-Sermaye ve İdeoloji}

Pandemi sonrasının kent mekânına ilişkin önerilerin, düşlerin gerçekleşip gerçekleşemeyeceği, mekân üretimindeki gerçeklerin değişip değişmeyeceğine bağlıdır. Mekân konusu, Aristoteles'ten bu yana güncelliğini yitirmemiş; mekâna ilişkin farklı kuramlar geliştirilmiştir. Lefebvre (2014), "(Toplumsal) mekân, (Toplumsal) bir üretimdir" görüşü ile mekânı politik ve toplumsal olarak ele alıp kavramsallaştırmaktadır. Lefebvre'ye göre mekân, ideolojiden ve politikadan ayrı ele alınamaz; çünkü mekân, politik süreçlerin belirlediği doğal ve tarihsel faktörlerin bir araya gelip güncellenmiş halidir. Castells, 1997 tarihli çalışmasında, Lefebvre'i destekler biçimde, kentlerin gelişmesine yönelik analizlerin toplumsal sınıf, siyaset ve iktidar arasındaki ilişkilerin kavranarak yapılması gerektiğinden bahsetmektedir.

Kapitalist üretim sisteminin sürekliliğini sağlama araçlarından birisi kentsel gelişmedir. Bir başka deyişle, kapitalizm mekân üreterek ve mekân üzerinde hâkimiyet kurarak varlığını sürdürür. Kentleşme sürecinde, kapitalist örgütlenme ve emeğin yeniden üretiminde sermayenin dolaşımı önemlidir; devlet ve sermaye arasındaki ilişkiler, kentsel gelişme ve değişmeyi açıklamaktadır (Feagin ve Gottdiener, 1988). Mekân üretiminde devlet müdahalesi, sermayenin gelişimi için engel teşkil eden arsa spekülasyonunu denetleme, arsa ve konut değerlerini yönlendiren kredi ve faiz politikaların belirleme, sermayenin lehine kentsel yatırımları üstlenme, yasal çerçeveyi oluşturma ve

\footnotetext{
9 Atılım Üniversitesi Mimarlık Bölümünün, 2020-21 Güz döneminde, 4. sınıf tasarım stüdyosunda bu konu verilmiş, dönem sonunda başarılı projeler elde edilmiştir.
} 
planlama aracilığıla toprak kullanımlarını düzenleme gibi mekanizmalar ile gerçekleşmektedir.

Kentsel mekân, yerleşme politikaları ve toprak kullanımı arasındaki bağlantı ile şekillenmektedir. Harvey'e (2015) göre, ulusal ya da uluslararası sermaye, yeni mekânlar üreterek, kent mekânındaki kârı/artı değeri elde ederek ayakta kalmaktadır; böylelikle kentsel mekân değiştirilip, dönüştürülmekte, toplumsal ve fiziksel yapı yeniden ve yeniden üretilmektedir. Kent mekânları, devlet müdahalesiyle; yani planlama aracılığıyla biçimlenmektedir. Planlama, 19. yüzyılda Sanayi Devrimi'nin bir sonucu olarak, kentsel gelişme gereksinimi sonucunda ortaya çıkmıs, kapsamlı yenileme ve genişleme programları gündeme gelmiştir. Kentsel planlama, toplumsal ve ekonomik örgütlerin karşı karşıya kaldığ1 çelişkiler ile eğilimlerin uzlaştırıldığı bir 'yer' dir. Üretim tarzının yapısal yasaları temelinde gerçekleşen planlama sürecinde, egemen sınıfların çıkarları öne çıkar. Dolayısıyla, bireylerin arsa üzerindeki çlkarları ile toplumsal yarar çelişir. Planlama, sınıfların, grupların çıkarlarını resmileştiren ayrıcalıklı bir araçtır; toplumun/topluluğun genel çkarları korunuyorsa planlamanın teknik yararlılığından söz edilebilir (Castells, 1997). Planlama ile bir yandan sorunlara rasyonel çözümler oluşturulurken bir yandan da farklı toplumsal çıkarlar ile kentsel işlevlerin bir bütün içinde ele alınması gerekir. Bu nedenle, planlamanın hangi toplumda, hangi amaçla ve nasıl yapıldığı önemlidir. Toplumdaki üretimin bireysel kâr düzenine dayandığı ve üretim araçlarının özel mülkiyette olduğu koşullarda ancak "yol gösterici" bir planlamadan söz edilebilir (Ural, 1976).

Lefebvre'ye (2014) göre mekân üçlü diyalektik bir süreçte üretilmektedir: Algılanan mekân-mekânsal pratikler, yaşanan mekân-temsil mekânları ve tasarlanan mekân-mekân temsillerinden oluşan mekânsal üçleme, birbirini tamamlamaktadır ve birbirlerinden ayrılamaz. Mekânsal pratik, bir toplumun mekânında gerçekleşen maddi pratiklerdir; çok genel olarak, gündelik hayatın bizatihi kendisidir. Günümüz pandemi sürecinin gündelik hayatı, mekân algısını değiştirmiş, yaşam tarzları farklılaşmış, mekân ve yaşam etkileşiminin farkındalığı artmıştır. Mekân temsilleri, mimarların, planciların, harita mühendislerinin, vb. eskizleri, çizimleri, teknik ifadeleri, kodları, vb.dir. Şengül (2016), planlamanın "egemen sınıflar için kendi ortak çkarlarına hizmet edecek biçimde, sermaye birikim sürecini sürekli kılacak" bir araç olarak işlev gördüğünü belirtmektedir. Ne yazık ki, kent planlama sürecinde, plancılar, mimarlar vb. ekonomik ve siyasi çıkarlar nedeniyle saf dışı bırakılmakta; bilgiyi ve tekniği kullanan tasarımcllar olmaktan öteye gidememektedir. Üst bö- 
lümde de söz edildiği gibi, 1980, özellikle 2000 sonrasında, kamusal/toplumsal yararı gözeten tasarımlar ve tasarımcıların uyarıları dikkate alınmamış, yapılaşma yoğunluğu giderek doğayı, tarım alanlarını yok etmiş, kent mekânları talan edilmiştir. Temsil mekânları, semboller ve imgeler aracılığıyla, doğrudan yaşanan mekândır; oturanların, kullananların, anıların somut mekânları olup, yaşananların ve kullananların sembollerini, imgelerini içerir. Düşük gelir gruplarının temsil mekânları olan gecekondu alanlarında yaşayanlar, pandemiden en çok etkilenen ve zarar gören kesim olmuştur.

\section{Sonuç Yerine: Pandemi Sonrasında Düşler Gerçek Olabilir mi?}

Pandemi sonrasının ekonomik yapılanması, üretim biçimi ve ideolojisi kent mekânlarının biçimlenmesini belirleyecektir. Geleceğin kent mekânlarına ilişkin, öneri ve düşlerin gerçekleşip gerçekleşmeyeceğini kestirmek zordur. Bununla birlikte, kent mekânının üretimi, sermaye ve ideoloji gerçekliği temelinde üç farklı seçenek üretilebilir:

a) Pandemi sonrasında, üretim ilişkilerinin sermayenin değil, toplumun lehine gerçekleşmesi durumunda, planlama ve mimarlık ilkeleri doğrultusunda tasarlanan kentsel, kamusal mekânlar uygulanabilir, toplumsal yararı gözeten, eşit, adil, yüksek kentsel yaşam kalitesi söz konusu olabilir. Toplumsal etkileşim ve paylaşım, doğal, açık, geniş ve ilkeli tasarlanmış kamusal alanlarda güvenli bir şekilde gerçekleşebilir.

b) İçinde bulunulan mevcut sistemin devam etmesi durumunda, kentsel ve kamusal mekânlarda göreceli iyileştirmeler yapılsa da, toplumu dikkate almayan kamusal alanların varlığı, üst ve üst-orta sınıfın mekânları ile orta ve düşük gelir grupları arasındaki mekânsal ayrışma ve toplumsal kutuplaşma devam edecektir

c) Pandemi sonrasında ekonomik yapılanmanın çöküşü bir distopyaya neden olabilir: Orta sınıfların yok olması sonucunda varlığını sürdüremeyen sermaye ile düşük gelir grupları karşı karşıya kalabilir, toplumların çöküşü başlayabilir.

Yeni dönemin olası sonuçlarını tahmin etmek çok kolay olmasa da, tarihsel süreçte yaşanan pandemilerin sonuçlarından da izlendiği gibi, yeni bir dünya düzeninin ve toplumsal yapılanmanın başlayacağı görüşlerine katılmak olanaklıdır. Doğal olarak, kent mekânları da değişen ekonomik ve toplumsal yapıya koşut olarak biçimlenecektir. 


\title{
Extended Abstract
}

\section{Two Faces of Urban Spaces after Pandemic: Dreams and Realities}

\author{
Emel Akın \\ ORCID: 0000-0001-5367-4373
}

In the process of COVID-19 disease, which started in December 2019 and was declared as a pandemic in March 2020, everyday life and the use of the urban space has evolved into a completely new process. In addition to the effects of the number of cases, vaccines, and the pandemic on individuals and lifestyles, the economic and social structure and urban spaces in post-Covid-19 era are the main actors of the world agenda.

The aim of this study is to think and construct the post-pandemic urban and public spaces through "dreams" and to seek answers to the question of whether the dreams can come true. In the article, pandemics and epidemics in the historical process are briefly mentioned; the urban spaces before the Covid-19 pandemic are briefly reviewed; two different "dreams" are being established regarding the future urban and public spaces in the post-Covid19 era. The "facts" of the space production process; in other words, the theoretical framework of the economic structure, planning and spatial formation relations is conveyed; whether the dreams set up in the article can come true is examined in this theoretical framework

In the historical process, besides three major plague pandemics, seven cholera and more than ten influenza pandemics that affected social structures, epidemic diseases of smallpox, yellow fever and malaria have been observed, and they have mostly created the conditions that reshaped social structures and spaces. In the article, two different "dreams" are set up for the urban and public spaces in the post-Covid-19 pandemic era. A city in a small "dream": Buildings built in agricultural and green areas can be demolished; street shopping can be revived instead of shopping malls; the functions of the shopping malls can be changed or they can be demolished to create public 
spaces, concert areas and squares. In addition, bike lanes can be made across the city, and the streets can be open to children, not the vehicles. In short, it is possible, or is it possible, to plan a city in favor of the individuals and the public who live there? A city in a big "dream": A model can be created in which basic urban functions will be provided through accommodation facilities, production, work, health care, education, shopping, social and cultural activities, non-motorized transport, etc. Each city unit may have a different production sector such as technology, textile, recycling, art from waste materials, food, alcohol, medicine, cleaning materials, and small home furnishings. All major urban functions can be carried out within a 15-minute walking distance, accessible to pedestrians or non-motorized vehicles. Within the walking distance, production, education, accommodation, working, entertainment, sports, etc. can be carried out together with people of different social classes. In other words, people from different economic, cultural and social capital groups can live together in the same places. Dreams have no limit: The owner, the workers and the employees of a factory, the principal, the teachers, the students and the attendants of a school or the chief physician, doctors, and the caregivers of a health center can live in and share the same social areas.

Planning and capital, which shape the urban space, are undoubtedly included in the "realities" of the space production process: Capital survives by producing new spaces and gaining profit / surplus value in the urban space; thus, the urban space is changed and transformed, and the social and physical structure is reproduced repeatedly. Urban spaces are shaped by state intervention through planning. The planning process, which takes place on the basis of the structural laws of the mode of production, is directly proportional to the interests of the ruling classes. At this point, it is possible to mention the contradiction between the interests of individuals on the land and the social benefit. Unfortunately, in the urban planning process, planners, architects, etc. are eliminated for economic and political interests; they cannot go beyond being designers who use their knowledge and techniques. In fact, as mentioned above, since the designers' warnings for public / social benefit were ignored, the density of housing has destroyed nature and agricultural areas, and urban spaces have been plundered since 1980, especially since 2000.

The post-pandemic economical structuring, ideology and mode of production will determine the formation of urban spaces. It is difficult to predict whether the dreams and suggestions for the urban spaces of the future will come true in the post-pandemic-19 era. However, based on the reality of capital and ideology, three different options have been produced in the article for 
the spaces of the future. a) After the pandemic, if the relations of production are realized in favor of the society, not the capital, urban public spaces that are designed in line with the principles of planning and architecture can be applied, and an equal and equitable urban life that pursues social benefit can be realized. Social interaction and sharing can take place safely in natural, open, large and well-designed public spaces. $b$ ) If the process we are in continues, public spaces will continue to lack the goal of social benefit in spite of relative improvements in urban and public spaces; the spatial segregation and social polarization between upper and upper-middle class spaces and middle and low income groups will continue. c) The collapse of economic restructuring after the pandemic can cause a dystopia; capital, which cannot survive without the support of the disappearing middle class, may come face to face with low-income groups; the collapse of societies could begin. Although it is not easy to predict the possible consequences of the new period, cities will be shaped in parallel with the changing economic and social structure.

\section{Kaynakça/References}

Akın, E. (2007). Kentsel gelişme ve kentsel rantlar: Ankara Örneği, Yerel Yönetimlerde "Dönüşüm" Sempozyumu, 17-19 Ekim 2007 Bildiriler Kitabı, TMMOB Peyzaj Mimarları Odas1, 79-90.

Akın, E. (2008). Space as a source of social power: Construction production process and architecture, Power and Architecture, 20. International Building and Life Congress Papers, 20-22 March 2008, TMMOB Mimarlar Odası Bursa Şubesi, 47-53.

Akın, E. (2013). Büyürken küçülen (baş)kent: Ankara, Başkent Oluşunun 90. Yılında Ankara:1923-2013, 7-8 Ekim 2013 Bildiriler Kitabı, Ankara Üniversitesi DTCF, 157-166.

Benevolo, L.(1981). Modern mimarlı̆̆ın tarihi birinci cilt sanayi devrimi. (A. Tokatlı, Çev.). İstanbul: Çevre Yayınları.

Beyaz, Z. (2021). Kapitalizmin pandemik sömürüsü bağlaminda salgın hastalıklara bir bakış, Çalışma ve Toplum, 2021/1, 181-204.

Choonara, J. (2020). Socialism in a time of pandemics, International Socialism, 2/166, 335.

Castells, M. (1997). Kent, sınıf, iktidar. (A. Erendil, Çev.). Ankara: Bilim ve Sanat Yayınevi.

Engels, F. (1977). Konut sorunu. (G. Özdural, Çev.). Ankara: Sol Yayınları.

Engels, F. (2019). Ingiltere'de emekçi sımıfların durumu. (O. Emre, Çev.). İstanbul: Ayrıntı Yayınları.

Feagin, J., ve Gottdiener, M., The paradigm shift in urban sociology, Urban Affairs Quarterly, Vol. 24, N. 2, December, 1988, 163-187.

Harvey, D. (2015). Sermayenin mekânları. (B. Kıcır, D. Koç, K. Tanrıyar, S. Yüksel, Çev.). İstanbul: Sel Yay. 
Harvey, D. (2020). Koronavirüs neoliberal yağmacılı̆̆a karşı doğanın bir intikamı. (K. Cenk, Çev.). 2 Mart 2021 tarihinde https://Uni-Versus.Org/2020/03/21/David-HarveyKapitalizm-Koronavirus/ adresinden erişildi.

Kıygı, G. (2020). 19. Yüzyılda salgın hastalıklar kentleri nasıl şekillendirdi. 20. Şubat 2021 tarihinde https://www.arkitera.com/gorus/19-yuzyilda-salgin-hastaliklar-kentleri-nasil-sekillendirdi-i/ adresinden erişildi.

Lefebvre, H. (2014). Mekânın üretimi. (I. Ergüden, Çev.). İstanbul: Sel Yayınları.

Lockett, E. (Goodwin, M., reviewed). (2020) What Is a Pandemic? 10. 07. 2021 tarihinde https://www.healthline.com/health/what-is-a-pandemic\#pandem ic-defined adresinden erişildi.

Özcü, A. ve Sayan Atanur G. (2020). Kovıd-19 pandemisinin kent yaşamına etkisi: kamusal alan üzerine değerlendirmeler, Paradoks Ekonomi, Sosyoloji ve Politika Dergisi, Cilt/Vol: 16 (2), 237-250. 12. Şubat 2021 tarihinde https://dergipark.org.tr/tr/download/article-file/1318317 adresinden erişildi.

Pamuk, Ş. (2020). Tarihte küresel salgınlar ve iktisadi sonuçları, 05. Şubat 2020 tarihinde https://24.com.tr/haber/sevket-pamuk-yazdi-tarihte-kuresel-salginlar-ve-iktisadi-sonuclari adresinden erişildi.

Peters, A. (2020). Paris's mayor has a dream of the "15-Minute City". 15 Eylül 2020 tarihinde https://www.fastcompany.com/90456312/pariss-mayor-has-a-dream-for-a15-minute-city adresinden erişildi.

Sağlık Bakanlığı Halk Sağlık Genel Müdürlüğü. (2019). Pandemik influenza ulusal hazırlık planı. 12 Şubat 2021 tarihinde https://grip.gov.tr/depo /saglik-calisanlari/ulusal_pandemi_plani.pdf adresinden erişildi.

Şengül, T. (2016). Planlama paradigmalarının dönüşümü üzerine eleştirel bir değerlendirme. Kentsel Planlama Kuramları içinde (ss. 59-114). M. Ersoy (Der.), Ankara: İmge Kitabevi,

Tuğaç, Ç. (2020). Kentsel sürdürülebilirlik ve kentsel dirençlilik perspektifinden tarihteki pandemiler ve Covid-19 pandemisi, Van Yüzüncü Yıl Üniversitesi Sosyal Bilimler Enstitüsü Dergisi, Salgın Hastalıklar Özel Sayısı, 259-292. 12 Şubat 2021 tarihinde https://dergipark.org.tr/tr/pub/yyusbed/issue/56115/772080 adresinden erişildi.

Tunç, A. ve Atıcı, F. Z. (2020). Dünyada ve Türkiye'de pandemilerle mücadele: Risk ve kriz yönetimi bağlamında bir değerlendirme. International Journal of Social Sciences, 5 (2), 329-362. https://doi.org/10.31454/usb.808685

Türkiye Bilimler Akademisi-TÜBA (2020a). Şeker M., Özer, A., Korkut, C. (Ed.). Küresel salgmm anatomisi insan ve toplumun geleceği. M. Şeker, A. Özer, C. Korkut (Der.) , Ankara: TDV Yayın Matbaacilık Tesisleri.

Türkiye Bilimler Akademisi-TÜBA (2020b). Şeker, M., Özer, A., Tosun, Z., Korkut, C., Doğrul, M. (Ed.). Covid-19 pandemi değerlendirme raporu. 10. 07. 2021 tarihinde https://grip.gov.tr/depo/saglik-calisanlari/ulusal_pandemi_plani.pdf adresinden erişildi. 
Ural, S. (1974). Türkiye'nin sosyal ekonomisi ve mimarlık 1923-1960," Mimarlik, 12 (12), 5-53.

Yiğit, İ. ve Gümüşçü, O. (2016). Manisa ve çevresinde salgın hastalıkların iskâna etkisi (XVI-XX. yy.). International Geography Symposium, 13-14 Ekim 2016, 15. Şubat 2020 tarihinde https://www.researchgate.net/publication/330347289_Manisa_ve_Cevresinde_Salgin_Hastaliklarin_Iskana_Etkisi_XVI-XX_yy adresinden erişildi. 